\title{
Analisis Kebutuhan untuk Pengembangan Bahan Ajar Fisiologi Hewan dan Manusia pada Jurusan Biologi
}

\author{
Arwinda Probowati ${ }^{1}$, Abdul Gofur ${ }^{1}$, Betty Lukiati ${ }^{1}$ \\ ${ }^{1}$ Pendidikan Biologi-Universitas Negeri Malang
}

\begin{tabular}{l} 
INFO ARTIKEL \\
\hline Riwayat Artikel: \\
Diterima: 09-07-2019 \\
Disetujui: $16-06-2020$ \\
\hline
\end{tabular}

Kata kunci:

teaching materials; animal and human physiology; biology;

bahan ajar;

fisiologi hewan dan manusia; biologi

\begin{abstract}
ABSTRAK
Abstract: This study aims to analyze the teaching material requirements animals and human physiology courses for undergraduate students of Biology Education, State University of Malang. This type of research is qualitative descriptive research. Data collected by questionnaires and structured interviews with lectures. The analysis of the results is shownn that $80 \%$ of students get difficulty in learning the animals and human physiology courses. The main learning resources used by students are worksheets, ebooks, handouts, and textbooks. Most students never learned a teaching material that contains research results done by lecturers, and a large part of students agree to be added teaching materials that contain research results to improve studens's knowledge. Based on the results, it will be developed modul that contains the results to support the physiology of animal and human physiologist.
\end{abstract}

\begin{abstract}
Abstrak: Penelitian ini bertujuan untuk menganalisis bahan ajar yang dibutuhkan pada matakuliah Fisiologi Hewan dan Manusia oleh mahasiswa S1 jurusan Biologi Universitas Negeri Malang. Penelitian ini merupakan penelitian deskriptif kualitatif. Data diperoleh melalui penyebaran angket dan melalui wawancara terstruktur terhadap dosen pengampu. Berdasarkan analisis hasil angket diketahui bahwa $80 \%$ mahasiswa masih mengalami kesulitan materi pada matakuliah Fisiologi Hewan dan Manusia. Sumber belajar utama yang digunakan oleh mahasiswa adalah berupa LKM, e-book, handout, dan buku teks. Sebagian besar mahasiswa menyatakan belum pernah menggunakan bahan ajar yang memuat hasil penelitian yang dilakukan dosen, dan menyatakan setuju untuk ditambahkanya bahan ajar yang memuat hasil penelitian untuk menambah wawasan dan meningkatkan pemahaman mahasiswa. Berdasarkan temuan tersebut, untuk menunjang perkuliahan fisiologi hewan dan manusia maka akan dikembangkan bahan ajar berupa modul cetak yang memuat hasil penelitian.
\end{abstract}

\section{Alamat Korespondensi:}

Arwinda Probowati

Pendidikan Biologi

Universitas Negeri Malang

Jalan Semarang 5 Malang

E-mail: arwinda.pw@gmail.com

Kurikulum pada pendidikan tinggi dalam penyusunannya harus memenuhi kriteria minimal sesuai dengan standar nasional pendidikan (SNP). Capaian kompetensi menurut lampiran Permenristekdikti Nomor 44 Tahun 2015 tentang SNP, lulusan sarjana diharuskan memiliki keterampilan umum antara lain; mampu menerapkan pemikiran yang kritis, logis, sistematis dan juga inovatif pada konteks Pengembangan dan juga implementasi logis, kritis, sistematis, dan inovatif pada konteks pengembangan dan implementasi IPTEK yang memperhatikan nilai sesuai dengan keahlian dan bidangnya. Pengintegrasian IPTEK dalam proses pembelajaran ini sesuai dengan KKNI level 6 untuk program sarjana. Lulusan sarjana diharapkan mampu menguasai konsep di bidang pengetahuan, menerapkan pemikiran yang logis, inovatif, dan kreatif serta menyelesaikan masalah di sekitarnya dengan memanfaatkan perkembangan IPTEK. IPTEK perlu diintegrasikan dalam semua kegiatan pembelajaran Biologi. Upaya untuk mencapai kompetensi sesuai SNP pada jurusan Biologi Fakultas Matematika dan Ilmu Pengetahuan Alam Universitas Negeri Malang, dapat diaplikasikan dalam matakuliah Fisiologi Hewan dan Manusia. Matakuliah ini merupakan salah satu matakuliah wajib yang diberikan kepada mahasiswa dengan beban sebanyak 4 SKS 6 JS.

Penguasaan konsep dalam bidang fisiologi merupakan bekal dalam dunia kerja nantinya, namun diharapakan mahasiswa selain faham mengenai mata pelajaran, tetapi juga mampu mengaitkannya dengan menggali bukti dari fenomena di kehidupan nyata dan juga mampu mengembangkan proses pembelajaran melalui observasi, mengukur, eksperimen, dan mengolah data (Hodosyová, Útla, Vnuková, \& Lapitková, 2015). Matakuliah Fisiologi Hewan dan Manusia berkaitan tentang fungsi tubuh hewan dan manusia, baik pada tingkat sel, jaringan, maupun organ. Capaiaan pembelajaran matakuliah (CPMK) pada RPS Fisiologi Hewan dan Manusia di Univeristas Negeri Malang, yaitu (1) mahasiswa mampu menguasai konsep, prinsip dan prosedur bidang fisiologi hewan yang terintegrasi dengam konsep dasar Biologi sel dan biokimia; (2) mampu merancang 
penyelidikan secara mandiri, kreatif, dan inovatif dalam menemukan, menganalisis, dan memecahkan permasalahan; (3) mengaplikasikan teknologi bidang Fisiologi Hewan dan Manusia dengan menghasilkan data akurat melalui pendekatan berbasis riset. Berdasarkan tuntutan CPMK tersebut, digunakan sebagai dasar dilakukannya analisis kebutuhan terhadap mahasiswa untuk mengetahui apakah terdapat permasalahan dalam pembelajaran matakuliah Fisiologi Hewan dan Manusia, dan untuk mengetahui apakah bahan ajar yang digunakan selama ini telah membantu mahasiswa dalam memenuhi tuntutan CPMK. Selain itu, dilakukan wawancara terstruktur terhadap dosen pengampu matakuliah Fisiologi Hewan dan Manusia untuk melengkapi hasil analisis yang dilakukan.

Menurut Prastowo (2012) bahan ajar adalah seperangkat yang berisi materi pembelajaran dalam membantu mencapai tujuan pembelajaran, yang disusun secara sistematis yang dapat dimanfaatkan untuk membantu proses pembelajaran. Bahan ajar yang memuat hasil penelitian dirasa mampu membantu mahasiswa untuk memenuhi tuntutan CPMK yang dietentukan, karena dapat membantu mahasiswa memndalami materi secara aplikatif (Primiani, 2014). Salah satu hasil penelitian yang dapat dijadikan materi dan berkaitan dengan fisiologi hewan dan manusia adalah mengenai penyakit diabetes mellitus tipe 2 yang menjadi ancaman dan permasalahan serius saat ini. Penyakit ini berhubungan dengan semua sistem tubuh hewan dan manusia sehingga sesuai dijadikan materi pembelajaran. Penelitian terkait penyakit ini berperan dalam membantu mahasiswa untuk mengeksplorasi dalam memahami teori dan menghubungkannya dengan fenomena di lingkungan sekitar yang berkaitan dengan materi Fisiologi Hewan dan Manusia (Parmin \& Peniati, 2012). Penelitian ini bertujuan untuk mengetahui bahan ajar yang perlu dikembangkan pada matakuliah Fisiologi Hewan dan Manusia dalam menunjang pembelajaran melalui analisis kebutuhan untuk mahasiswa sesuai dengan tahap Analyze pada pendekatan ADDIE.

\section{METODE}

Penelitian ini termasuk dalam penelitian deskriptif kualitatif bertujuan untuk menemukan permasalahan pada matakuliah Fisiologi Hewan dan Manusia serta mencari solusi dari permasalahan tersebut. Penelitian dilakukan pada bulan Mei 2018 di Universitas Negeri Malang mwlalui analisis kebutuhan. Analisis kebutuhan dilakukan terhadap mahasiswa menggunakan angket analisis kebutuhan dengan jumlah responden sebanyak 20 mahasiswa dari S1 Biologi di Universitas Negeri Malang, untuk memperkuat hasil dari analisis kebutuhan dilakukan wawancara terstruktur terhadap dosen pengampu matakuliah Fisiologi Hewan dan Manusia. Teknik pengumpulan data untuk mahasiswa yaitu menggunakan angket analisis kebutuhan dalam bentuk google form yang terdiri dari tujuh buah pertanyaan. Pertanyaan yang disajikan merupakan pertanyaan tertutup yang mencakup pilihan ganda dan disertai dengan uraian alasan sesuai dengan keadaan yang sebenarnya. Wawancara terstruktur terhadap dosen pengampu, menggunakan pedoman wawancara yang terdiri dari 13 buah pertanyaan. Daftar pertanyaan untuk angket analisis kebutuhan mahasiswa disajikan pada tabel 1, sedangkan daftar pertanyaan pedoman wawancara terhadap dosen pengampu disajikan pada tabel 2.

Tabel 1. Daftar Pertanyaan Angket Analisis Kebutuhan Mahasiswa Prodi Pendidikan Biologi

\begin{tabular}{|c|c|c|}
\hline Kriteria & No. Pertanyaan & Pertanyaan \\
\hline $\begin{array}{l}\text { Metode yang } \\
\text { diterapkan }\end{array}$ & 1 & $\begin{array}{l}\text { Bagaimanakah metode yang diterapkan di perkuliahan Fisiologi Hewan dan Manusia selama ini? } \\
\text { (diperbolehkan memberi lebih dari } 1 \text { pilihan jawaban) }\end{array}$ \\
\hline $\begin{array}{l}\text { Kendala dalam } \\
\text { pembelajaran }\end{array}$ & 2 & $\begin{array}{l}\text { Apakah terdapat kesulitan materi pada materi tertentu dalam matakuliah tersebut? Apabila ya, } \\
\text { tuliskan materi apa yang dirasa sulit dan sertakan alasannya! }\end{array}$ \\
\hline \multirow[t]{2}{*}{$\begin{array}{l}\text { Sumber belajar } \\
\text { yang digunakan }\end{array}$} & 3 & $\begin{array}{l}\text { Bahan ajar apa yang digunakan dosen untuk menunjang perkuliahan matakuliah Fisiologi Hewan } \\
\text { dan Manusia? (diperbolehkan memberi lebih dari } 1 \text { pilihan jawaban) }\end{array}$ \\
\hline & 4 & $\begin{array}{l}\text { Apakah dosen menyediakan bahan ajar yang memuat hasil penelitian yang pernah dilakukan? } \\
\text { Apabila ya, pada topik apa yang ditunjang dengan penelitian yang telah dilakukan? }\end{array}$ \\
\hline \multirow[t]{3}{*}{$\begin{array}{l}\text { Bahan ajar yang } \\
\text { dibutuhkan }\end{array}$} & 5 & $\begin{array}{l}\text { Apakah perlu ditambahkan bahan ajar berbasis penelitian untuk mendampingi bahan ajar yang } \\
\text { telah ada? }\end{array}$ \\
\hline & 6 & $\begin{array}{l}\text { Matakuliah Fisiologi Hewan dan Manusia merupakan matakuliah yang mengkaji fungsi organ dan } \\
\text { penyakit yang menyebabkan disfungsi organ pada pada makhluk hidup. Salah satu topik } \\
\text { bahasannya adalah membahas mengenai suatu penyakit. Apakah saudara pernah menggunakan } \\
\text { bahan ajar berbasis penelitian yang membahas suatu penyakit? }\end{array}$ \\
\hline & 7 & $\begin{array}{l}\text { Simaklah pernyataan berikut } \\
\text { Penyakit degenerative adalah penyakit yang timbul diakibatkan menurunnya fungsi sel tubuh dari } \\
\text { kewadaan yang awalnya normal berubah menjadi lebih buruk. Di Indonesia, penyakit degeneratif } \\
\text { mulai menjadi perhatian dikarenakan angka kejadian dan kematian yang semakit meningkat. } \\
\text { Kebanyakan penyakit degeneratif dapat disembuhkan, namun ada beberapa kasus yang } \\
\text { peneyembuhannya perlu waktu yang lama. Melihat kasus tersebut, apakah perlu dikembangkan } \\
\text { bahan ajar berbasis penelitian terkait penyakit degeneratif? }\end{array}$ \\
\hline
\end{tabular}


Tabel 2. Daftar Pertanyaan Angket Wawancara Terhadap Dosen Pengampu Matakuliah Anatomi Fisiologi Hewan dan Manusia

\begin{tabular}{|c|c|c|}
\hline Kriteria & No. Pertanyaan & Pertanyaan \\
\hline Riwayat dosen pengampu & 1 & Berapa lama Bapak/Ibu mengampu mata kuliah anatomi fisiologi hewan dan manusia? \\
\hline $\begin{array}{l}\text { Kendala dalam mengampu } \\
\text { matakuliah }\end{array}$ & 2 & $\begin{array}{l}\text { Apakah terdapat kendala yang ditemui selama Bapak/Ibu menampu mata kuliah ini? } \\
\text { Mohon berikan alasan atas jawaban yang Bapak/Ibu berikan! }\end{array}$ \\
\hline \multirow{4}{*}{$\begin{array}{l}\text { Metode yang digunakan } \\
\text { pada matakuliah fisiologi } \\
\text { hewan dan manusia }\end{array}$} & 3 & $\begin{array}{l}\text { Bagaimanakah metode pembelajaran yang Bapak/Ibu terapkan pada perkuliahan anatomi } \\
\text { fisiologi hewan dan manusia selama ini?? }\end{array}$ \\
\hline & 4 & $\begin{array}{l}\text { Apakah mahasiswa aktif ketika mengikuti mata kuliah anatomi fisiologi hewan dan } \\
\text { manusia? Mohon berikan alasan atas jawaban yang Bapak/Ibu berikan! }\end{array}$ \\
\hline & 5 & $\begin{array}{l}\text { Bagaimanakah ketercapaian pembelajaran pada mata kuliah anatomi fisiologi hewan dan } \\
\text { manusia selama ini? Mohon diberikan alasan atas jawaban yang Bapak/Ibu berikan! }\end{array}$ \\
\hline & 6 & $\begin{array}{l}\text { Dari pengalaman Bapak/Ibu, apakah pada matakuliah anatomi fisiologi hewan terdapat } \\
\text { materi yang dianggap sulit oleh mahasiswa? Apabila ya, pada topik apa saja yang } \\
\text { dianggap sulit bagi mahasiswa? }\end{array}$ \\
\hline \multirow{4}{*}{$\begin{array}{l}\text { Sumber belajar yang } \\
\text { digunakan pada } \\
\text { matakuliah fisiologi } \\
\text { hewan dan manusia }\end{array}$} & 7 & $\begin{array}{l}\text { Bahan ajar apa yang Bapak/Ibu gunakan untuk menunjang perkuliahan mata kuliah anatomi } \\
\text { fisiologi hewan dan manusia? (Diperbolehkan untuk memberikan lebih dari satu jawaban). }\end{array}$ \\
\hline & 8 & $\begin{array}{l}\text { Apakah bahan ajar yang digunanakan Bapak/Ibu sudah dapat membantu mahasiswa dalam } \\
\text { mencapai capaian pembelajaran matakuliah anatomi fisiologi hewan dan manusia? Mohon } \\
\text { berikan alasan atas jawaban yang Bapak/Ibu berikan! }\end{array}$ \\
\hline & 9 & $\begin{array}{l}\text { Apakah Bapak/Ibu sebagai dosen pengampu pernah membuat bahan ajar berbasis penelitian } \\
\text { untuk menunjang perkuliahan anatomi fisiologi hewan dan manusia? Apabila ya, pada } \\
\text { topik apa yang dibelajarkan? }\end{array}$ \\
\hline & 10 & $\begin{array}{l}\text { Apakah pada topik yang dianggap sulit bagi mahasiswa pada mata kuliah anatomi fisiologi } \\
\text { hewan dan manusia sudah tersedia bahan ajar yang berbasis dengan penelitian? }\end{array}$ \\
\hline \multirow[t]{3}{*}{$\begin{array}{l}\text { Bahan ajar yang } \\
\text { dibutuhkan }\end{array}$} & 11 & $\begin{array}{l}\text { Apakah perlu ditambahkan bahan ajar berbasis penelitian untuk mendampingi bahan ajar } \\
\text { yang telah ada? Mohon berikan alasan atas jawaban yang Bapak/Ibu berikan! }\end{array}$ \\
\hline & 12 & $\begin{array}{l}\text { Apakah bahan ajar yang digunakan pada mata kuliah anatomi fisiologi hewan dan } \\
\text { manusia selama ini ada yang membahas tentang suatu penyakit yang salah satunya adalah } \\
\text { tentang penyakit degeneratif yang mulai menjadi perhatian diakrenakan angka kejadian dan } \\
\text { kematian yang semakin meningkat akibat penyakit tersebut? }\end{array}$ \\
\hline & 13 & $\begin{array}{l}\text { Bagaimana menurut pendapat Bapak/Ibu apabila pada mata kuliah anatomi fisiologi hewan } \\
\text { dan manusia dikembangkan suatu bahan ajar berbasis penelitian untuk suatu penyakit } \\
\text { degeneratif yang juga dapat menambah wawasan mahasiswa dalam mempelajari anatomi } \\
\text { fisiologi hewan dan manusia? Mohon diberikan alasan atas jawaban yang Bapak/Ibu } \\
\text { berikan! }\end{array}$ \\
\hline
\end{tabular}

\section{HASIL}

Hasil analisis kebutuhan terhadap mahasiswa digunakan sebagai dasar untuk mengetahui permasalahan yang ditemukan serta mencari solusi terhadap pembelajaran fisiologi hewan dan manusia. Sesuai dalam tahapan Analyze dalam rancangan instruksional pendekatan ADDIE, setelah dilakukan analisis mengenai permasalahan di lapangan, tahapan selanjutnya adalah melakukan analisis tujuan pengembangan, sasaran pengembangan, dan identifikasi komponen yang diperlukan pada tahap pengembangan, menentukan cara penyampaian produk, dan menyusun mengenai rencana untuk melaksanakan pengembangan.

\section{Analisis Permasalahan di Lapangan}

Permasalahan yang dianalisis yaitu mengenai kendala dalam pembelajaran, penyebab dari kendala tersebut, serta solusi yang diharapkan untuk mengatasi kendala/permasalah tersbeut. Hasil angket analisis kebutuhan di Universitas Negeri Malang diperoleh beberapa informasi yang disajikan pada tabel 3. 
Tabel 3. Hasil Analisis Kebutuhan Mahasiswa Pendidikan Biologi Universitas Negeri Malang

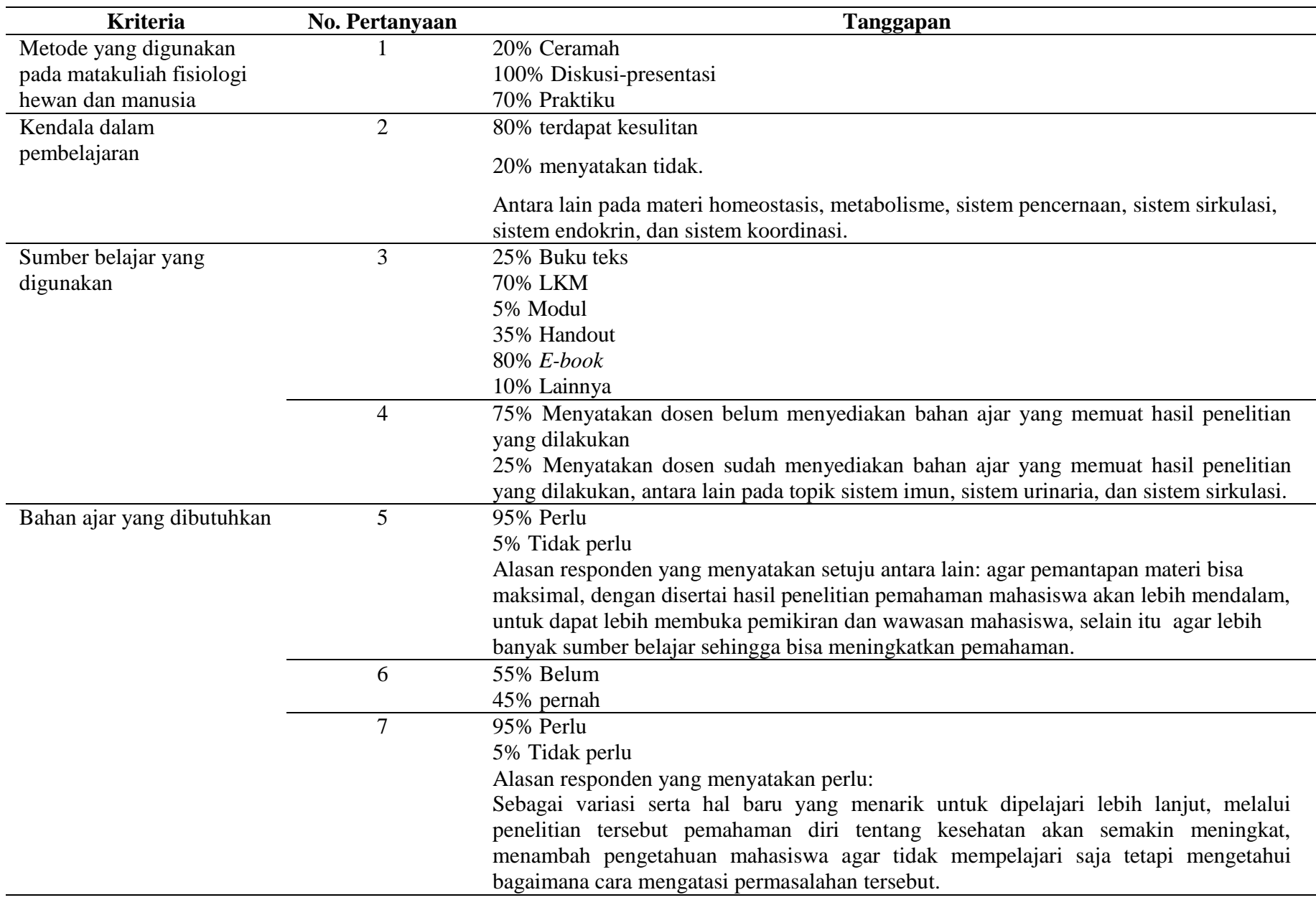

Tabel 4. Hasil Angket Wawancara Terhadap Dosen Pengampu Matakuliah Fisiologi Hewan dan Manusia

\begin{tabular}{|c|c|c|}
\hline Kriteria & No. Pertanyaan & Pertanyaan \\
\hline Riwayat dosen pengampu & 1 & $>5$ tahun \\
\hline $\begin{array}{l}\text { Kendala dalam mengampu matakuliah } \\
\text { fisiologi hewan dan manusia }\end{array}$ & 2 & $\begin{array}{l}\text { Masih monotonnya model pembelajaran yang diterapkna, materi bersifat } \\
\text { abstrak sehingga masih perlu bahan ajar untuk membantu untuk mempelajari } \\
\text { konsep fisiologi, }\end{array}$ \\
\hline \multirow{4}{*}{$\begin{array}{l}\text { Metode yang digunakan pada } \\
\text { matakuliah fisiologi hewan dan } \\
\text { manusia }\end{array}$} & 3 & Ceramah, diskusi, praktikum. \\
\hline & 4 & $\begin{array}{l}\text { Ya, tetapi model pembelajaran kurang atraktif sehingga keaktifan belum } \\
\text { maskimal dan hal yang didiskusikan mahsiswa belum sampai tahap analisis. }\end{array}$ \\
\hline & 5 & $\begin{array}{l}\text { Baik, tetapi masih ada banyak hal yang belum maksimal salah satunya } \\
\text { bagaimana matakuliah ini bsia menghasilkan banyak ide untuk riset. }\end{array}$ \\
\hline & 6 & $\begin{array}{l}\text { Ya. Antara lain sistem sirkulasi, sistem pencernaan, system indera, dan } \\
\text { system ekskresi. }\end{array}$ \\
\hline \multirow{4}{*}{$\begin{array}{l}\text { Sumber belajar yang digunakan pada } \\
\text { matakuliah fisiologi hewan dan } \\
\text { manusia sudah dapat membantu } \\
\text { mahasiswa untuk mencapai capaian } \\
\text { pembelajaran matakuliah }\end{array}$} & 7 & Buku, LKM, handout, e-book. \\
\hline & 8 & $\begin{array}{l}\text { Sudah. Meskipun bahan ajar yang diberikan hanya membantu tapi masih } \\
\text { diperlukan inovasi bahan ajar lainnya, dan hanya sebagian saja yang tercapai. }\end{array}$ \\
\hline & 9 & Belum pernah \\
\hline & 10 & Belum pernah. \\
\hline \multirow[t]{3}{*}{ Bahan ajar yang dibutuhkan } & 11 & $\begin{array}{l}\text { Ya. Agar mahasiswa mendapatkan bahan ajar lebih banyak untuk memahami } \\
\text { materi fisiologi terutama untuk belajar mandiri. }\end{array}$ \\
\hline & 12 & Tidak. Bahan ajar kebanyakan berupa $e$-book dan kasus yang ada di lapangan. \\
\hline & 13 & $\begin{array}{l}\text { Setuju, untuk dapat menambah sumber bagi mahasiswadalam memahami } \\
\text { konsep fisiologi. }\end{array}$ \\
\hline
\end{tabular}




\section{Analisis Tujuan Pengembangan}

Menurut hasil dari analisis kebutuhan terhadap mahasiswa dapat diketahui bahwa mahasiswa masih mendapati kesulitan pada materi tertentu. Hal ini juga didukung oleh hasil wawancara terhadap dosen pengampu matakuliah Fisiologi Hewan dan Manusia bahwa mahasiswa masih mengalami kesulitan pada matakuliah tersebut. Sebagaian besar mahasiswa menyatakan bahwa belum tersedianya bahan ajar yang memuat hasil penelitian, dan menginginkan bahan ajar yang memuat hasil penelitian untuk menambah sumber belajar dan membantu untuk memahami konsep fisiologi. Berdasarkan hal tersebut, maka produk yang akan dikembangkan berupa bahan ajar modul cetak berdasarkan hasil penelitian mengenai penyakit diabetes tipe 2 .

\section{Analisis Sasaran Pengembangan}

Penelitian pengembangan ditujukan kepada mahasiswa S1 Program Studi Pendidikan Biologi Universitas Negeri Malang yang sedang menempuh matakuliah Fisiologi Hewan dan Manusia.

\section{Mengidentifikasi Komponen yang Diperlukan dalam Pengembangan}

Sumber daya yang dibutuhkan dalam penelitian pengembangan berupa fasilitas yang menunjang dalam pembelajaran dan juga didukung dengan sumber daya manusia. Fasilitas pembelajaran itu antara lain ruang kelas yang ditunjang dengan peralatan pembelajaran, seperti LCD, internet, dan laptop. Sumber daya manusia yang dibutuhkan yaitu ahli bahan ajar, ahli materi dan dosen sebagai praktisi lapangan serta mahasiswa yang sudah menempuh matakuliah Fisiologi Hewan dan Manusia untuk uji kepraktisan produk.

\section{Menentukan Cara Penyampaian Produk dan Menyusun Rencana Pelaksanaan Pengembangan}

Penyampaian produk dilakukan terhadap kelompok kecil sebanyak 20 mahasiswa dengan diberikan modul yang dikembangkan serta angket kepraktisan. Angket kepreaktisan digunakan untuk mengetahui apakah modul yang dikembangkan menarik dan mudah dipahami oleh mahasiswa. Rencana dikembangkannya produk pada bulan Januari—Februari 2019.

\section{PEMBAHASAN}

Hasil analisis kebutuhan terhadap mahasiswa diketahui bahwa 80\% mahasiswa masih mengalami kesulitan materi dikarenakan belum tersedianya bahan ajar yang membantu mahasiswa untuk mengaitkan konsep fisiologi dengan permasalahan dan kehidupan sehari-hari sehingga diperlukan suatu sumber belajar yang dapat membantu dalam memahami konsep-konsep fisiologi agar lebih kontekstual dan mudah dipahami. Proses pembelajaran yang dilakukan pada matakuliah Fisiologi Manusia cenderung dilaksanakan dengan menggunakan metode ceramah, diskusi-presentasi. Metode ini dirasa kurang dapat menjelaskan materi secara mendalam, serta kurang memberikan contoh kontekstual yang disajikan. Sumber belajar utama yang digunakan oleh mahasiswa adalah berupa LKM, e-book, handout, dan buku teks, namun masih diperlukan inovasi bahan ajar lainnya dengan tujuan membantu mempermudah proses belajar. Terkait bahan ajar yang digunakan, juga diperoleh informasi bahwa dosen belum menyediakan bahan ajar berdasarkan hasil penelitian yang dilakukan. Berdasarkan temuan permasalah tersebut, mahasiswa membutuhkan alternatif bahan ajar yang memuat contoh kontekstual dan dapat memudahkan mahasiswa dalam pelaksanaan pembelajaran.

Bahan ajar merupakan bagian penting dalam proses pembelajaran. Sebagaimana pendapat (Mulyasa, 2006), bahan ajar merupakan sumber ajar yang dapat didefisinkan sebagai sesuatu yang memuat pesan pembelajaran, baik yang bersifat khusus maupun bersifat umum untuk kepentingan pembelajaran. Sumber belajar kontekstual yang dapat dimanfaatkan dan membantu pembelajran adalah bahan yang didukung dengan hasil penelitian. Penelitian yang dapat digunakan sebagai sumber informasi dan bersifat kontekstual adalah mengenai penyakit-penyakit yang ada di masyarakat. Salah satu penyakit yang menjadi perhatian dan mengancam masyarakat di negara berkembang seperti Indonesia saat ini adalah Diabetes mellitus tipe 2. Kasus mengenai DM tipe 2 ini berkaitan dengan semua sistem tubuh hewan dan manusia sehingga cocok untuk dijadikan materi pembelajaran pada matakuliah Fisiologi Hewan dan Manusia.

Penelitian pengembangan bahan ajar dirasa dapat memperantarai penelitian eksperimen dengan praktik pendidikan, salah satu diantaranya melalui pengembangan bahan ajar yang memuat hasil penelitian (Oktaviana, Sumitro, \& Lestari, 2015). Hasil penelitian dapat dijadikan sebagai sumber belajar kontekstual (Amin, 2010) dan dapat memberikan pembelajaran faktual bagi mahasiswa dalam pembelajaran (Parmin dan Peniati, 2012). Mengacu dari temuan permasalahan tersebut, dibutuhkan alternatif bahan ajar yang memuat contoh kontekstual dan dapat memudahkan mahasiswa dalam pelaksanaan pembelajaran.

Disesuaikan dengan karakteristik materi ajar yang akan disajikan dengan kebutuhan mahasiswa, bahan ajar dapat dibuat dalam berbagai bentuk (Depdiknas, 2008). Salah satu jenis bahan ajar adalah modul. Modul adalah jenis bahan ajar yang dikemas secara utuh dan sistematis, yang didalamnya berisikan seperangkat pengalaman belajar terencana dan keberadaan modul ini diharapkan dapat membantu berlatih secara mandiri, mengungkapkan pendapat dan malatih logika berfikir agar berkembang (Novana, Sajidan, \& Maridi, 2014). Modul dalam suatu pembelajaran juga dapat meningkatkan efisiensi dan efektivitas pembelajaran dalam mencapai kompetensi secara optimal (Septianu, Sudarmin, \& Widiyatmoko, 2014), memudahkan memahami permasalahan atau materi yang akan dibahas (Widyaningrum, Sarwanto, \& Karyanto, 2013). 
Upaya untuk mendapatkan modul yang sesuai dengan kebutuhan, maka dalam mengembangkan modul perlu dipadu dengan model pembelajaran. Model pembelajaran yang akan dipadukan dalam penelitian lanjutan adalah inkuiri terbimbing. Inkuiri terbimbing adalah rangkaian kegiatan pembelajaran yang mengajak peserta didik untuk terlibat dalam proses berpikir analistis dan kreatif (Llewellyn, 2013) serta mencari hingga menemukan jawaban secara mandiri terhadap permasalahan yang dipecahkan melalui keterampilan proses (Peffer \& All, 2015) dan sikap ilmiah (Heri, 2014).

\section{SIMPULAN}

Berdasarkan hasil penelitian tersebut, disimpulkan bahwa diperlukan pengembangan bahan ajar yang memuat hasil penelitian yang dilakukan terkait kasus penyakit yang menjadi ancaman serius saat ini, yaitu Diabetes Mellitus Tipe 2. Kasus ini berkaitan dengan semua sistem tubuh hewan dan manusia sehingga cocok untuk dijadikan materi pembelajaran. Bahan ajar yang akan dikembangkan adalah modul Fisiologi Hewan dan Manusia berdasarkan hasil penelitian berbasis inkuiri terbimbing. Pengembangan modul ini mengacu pada tahapan rancangan instruksional pendekatan ADDIE dan dapat dilanjutkan ke tahap Design, Develop, Implement, dan Evaluate.

\section{DAFTAR RUJUKAN}

Amin, M. (2010). Implementasi Hasil-Hasil Penelitian Bidang Biologi Dalam Pembelajaran. 12-18.

Depdiknas. (2008). Penulisan Modul. Jakarta: Direktorat Tenaga Pendidikan, Direktorat Jenderal Peningkatan Mutu, Pendidik dan Tenaga Kependidikan, Departemen Pendidikan Nasional.

Heri, E. A. (2014). Pengembangan Modul Latihan Keterampilan Proses Sains untuk SMA/MA Kelas X pada Materi Kinematika Gerak. Tesis tidak diterbitkan. Universitas Sebelas Maret, Surakarta.

Hodosyová, M., Útla, J., Vnuková, P., \& Lapitková, V. (2015). The Development of Science Process Skills in Physics Education. Procedia - Social and Behavioral Sciences, 186, 982-989. https://doi.org/10.1016/j.sbspro.2015.04.184

Llewellyn, D. J. (2013). Teaching High School Science through Inquiry and Argumentation. USA: Corwin.

Mulyasa, E. (2006). Menjadi Guru Profesional Menciptakan Pembelajaran Kreatif dan Menyenangkan. Bandung: Remaja Rosdakarya.

Novana, T., Sajidan, \& Maridi. (2014). Pengembangan Modul Inkuiri Terbimbing Berbasis Potensi Lokal pada Materi Tumbuhan Lumut (Bryophyta ) dan Tumbuhan Paku (Pteridophyta). Jurnal Inkuiri, 3(2), 108-122.

Oktaviana, I., Sumitro, S., \& Lestari, U. (2015). Pengembangan Bahan Ajar Berbasis Penelitian Karakterisasi Protein Membran Sperma pada Matakuliah Bioteknologi. Jurnal Florea, 2(2), 33-42.

Parmin, \& Peniati, E. (2012). Pengembangan Modul Matakuliah Strategi Belajar Mengajar IPA Berbasis Hasil Penelitian Pembelajaran. Jurnal Pendidikan IPA Indonesia, 1(1), 8-15.

Peffer, M., \& All, E. (2015). Science Classroom Inquiry (SCI) Simulations: A Novel Method to Scaffold Science Learning. Plos One Journal, 10(3), 1-11.

Prastowo, A. (2012). Panduan Kreatif Membuat Bahan Ajar Inovatif. Yogyakarta: Diva Press.

Primiani, C. (2014). Pengembangan Buku Ajar Berbasis Penelitian Bahan Alam Lokal sebagai Estrogenik pada Matakuliah Fisiologi Hewan. Prosiding Mathematics and Sciences Forum.

Septianu, E., Sudarmin, \& Widiyatmoko, A. (2014). Pengembangan Modul IPA Terpadu Tema Perubahan Zat Berbasis Discovery untuk Meningkatkan Keterampilan Generik dan Hasil Belajar Siswa. Unnes Science Education Journal, 3(3).

Widyaningrum, R., Sarwanto, \& Karyanto, P. (2013). Pengembangan Modul Berorientasi POE (Predict, Observe , Explain) Berwawasan Lingkungan Padamateri Pencemaran untuk Meningkatkan. Jurnal Bioedukasi, 6(1), 100-117. 